\title{
TABLE OF LEGISLATION AND OFFICIAL DOCUMENTS
}

\section{LEGISLATION}

\section{Directives}

Council Directive 64/221/EEC of 25

February 1964 on the co-ordination of special measures concerning the movement and residence of foreign nationals which are justified on grounds of public policy, public security or public health, OJ 56, 4 April 1964, p. 850

Council Directive 65/65/EEC of 26 January

1965 on the approximation of provisions laid down by law, regulation or administrative action relating to proprietary medicinal products, OJ 22,

9 February 1965, p. 369 1.09

Council Directive 71/305/EEC of 26 July 1971 concerning the coordination of procedures for the award of public works contracts, OJ L 185, 16 August 1971, p. 5 3.01

Council Directive 76/207/EEC of 9

February 1976 on the implementation of the principle of equal treatment for men and women as regards access to employment, vocational training and promotion, and working conditions, OJ L 39, 14 February 1976, p. 40 1.09

Second Council Directive 77/91/EEC of 13

December 1976 on coordination of safeguards which, for the protection of the interests of members and others, are required by Member States of companies within the meaning of the second paragraph of Article 58 of the Treaty, in respect of the formation of public limited liability companies and the maintenance and alteration of their capital, with a view to making such safeguards equivalent, OJ L 26, 31 January 1977, p. 1 ........................ 1.09

Third Council Directive 78/855/EEC of 9 October 1978 based on Article 54(3)(g) of the Treaty concerning mergers of public limited companies, OJ L 295, 20 October 1978, p. 36 1.09

Council Directive 84/450/EEC of 10

September 1984 relating to the approximation of the laws, regulations and administrative provisions of the Member States concerning misleading advertising, OJ L 250, 19 September 1984, p. 17 5.02

Council Directive 85/337/EEC of 27 June 1985 on the assessments of the effects of certain public and private projects on the environment, OJ L 175, 25 July 1985, p. 40 1.10

Council Directive 85/374/EEC of 25 July 1985 on the approximation of the laws, regulations and administrative provisions of the Member States concerning liability for defective products, OJ L 210, 7 August 1985, p. 29 (Product Liability

Directive) $1.09,5.33$

Council Directive 85/577/EEC of 20

December 1985 to protect the consumer in respect of contracts negotiated away from business premises, OJ L 372, 31 December 1985, p. 31 ("Doorstep Selling

Directive") $5.23,8.12$

Council Directive 89/665/EEC of 21

December 1989 on the coordination of laws, regulations and administrative provisions relating to the application of 
review procedures to the award of public supply and public works contracts, OJ L 395, 30 December 1989, p. 33 ("Public Sector Remedies

Directive") $1.10,3.09$

Council Directive 90/314/EEC of 13 June 1990 on package travel, package holidays and package tours, OJ L 158, 23 June 1990, p. 59 ("Package Travel Directive") 5.03, 5.23, 5.34, 7.06,

$7.20,8.01,12.15$

Council Directive 92/13/EEC of 25

February 1992 coordinating the laws, regulations and administrative provisions relating to the application of rules on the procurement procedures of entities operating in the water, energy, transport and telecommunications sectors, OJ L 76, 23 March 1992, p. 14 ("Utilities Remedies

Directive") 1.10, 3.09

Council Directive 93/13/EEC of 15 April 1993 on unfair terms in consumer contracts, OJ L 95, 21 April 1993, p. 29 ("Unfair Terms

Directive") 1.15

Council Directive 93/83/EEC of 27

September 1993 on the coordination of certain rules concerning copyright and rights related to copyright applicable to satellite broadcasting and cable retransmission, OJ L 248, 6 October 1993, p. 15 4.02

Directive 95/46/EC of the European

Parliament and of the Council of 24 October 1995 on the protection of individuals with regard to the processing of personal data and of the free movement of such data, OJ L 281, 23 November 1995, p. 13 ("Data

Protection Directive") 1.10

Directive 96/9/EC of the European

Parliament and of the Council of 11

March 1996 on the legal protection of databases, OJ L 77/20, 27 March 1996, p 20 ("Database Directive") 8.05
Council Directive 97/80/EC of 15

December 1997 on the burden of proof in cases of discrimination based on sex, OJ L 14, 20 January 1980, p. 6 .... 1.09

Directive 98/6/EC of the European Parliament and of the Council of 16 February 1997 on consumer protection in the indication of the prices of products offered to consumers, $\mathrm{OJ} \mathrm{L}$ 80, 18 March 1998, p. $27 \quad$............ 5.02

Directive 98/27/EC of the European Parliament and of the Council of 19 May 1998 on injunctions for the protection of consumers' interests, OJ L 166, 11 June 1998, p. 5130

Directive 98/43/EC of the European Parliament and of the Council of 6 July 1998 on the approximation of the laws, regulations and administrative provisions of the Member States relating to the advertising and sponsorship of tobacco products, OJ L 213, 30 July 1998, p. 9 10.02

Directive 98/71/EC of the European Parliament and of the Council of 13 October 1998 on the legal protection of designs, OJ L 289, 28 October 1998, p. 28

Council Directive 1999/31/EC on the landfill of waste, OJ L 182, 16 July 1999 , p. 1

Directive 1999/34/EC of the European Parliament and of the Council of 10 May 1999 amending Council Directive 85/374/EEC on the approximation of the laws, regulations and administrative provisions of the Member States concerning liability for defective products, OJ L 141, 4 June 1999, p. 20 ("Product Liability Amending Directive") 5.33

Directive 1999/44/EC of the European Parliament and of the Council of 25 May 1999 on certain aspects of the sale of consumer goods and associated guarantees, OJ L 171, 7 July 1999, 
p. 12 ("Consumer Sales

Directive") 5.03

Directive 1999/93/EC of the European

Parliament and of the Council of 13

December 1999 on a Community

framework for electronic signatures,

OJ L 13, 19 January 2000, p. 12

("Electronic Signatures

Directive")

Directive 2000/31/EC of the European

Parliament and of the Council of 8

June 2000 on certain legal aspects of

information society services, in

particular electronic commerce, in the

Internal Market (Directive on

electronic commerce), OJ L 178, 17

July 2000, p. 1 ("E-Commerce

Directive")

Council Directive 2000/43/EC of 29 June

2000 implementing the principle of

equal treatment between persons

irrespective of racial or ethnic origin,

OJ L 180, 19 July 2000, p. 22 ("Racial

Equality Directive") 9.18

Directive 2001/29/EC of the European

Parliament and of the Council of 22

May 2001 on the harmonisation of certain aspects of copyright and related rights in the information society, OJ L 167, 22 June 2001, p. 10 ("Infosoc

Directive") 4.02

Directive 2001/83/EC of the European

Parliament and of the Council of 6

November 2001 on the Community code relating to medicinal products for human use, OJ L 311, 28 November 2001, p. 67 1.09

Directive 2001/95/EC of the European

Parliament and of the Council of 3

December 2001 on general product safety, OJ L 11, 15 January 2002, p. 4

("Product Safety Directive") .5 .03

Directive 2002/58/EC of the European Parliament and of the Council of 12 July 2002 concerning the processing of personal data and the protection of privacy in the electronic communications sector (Directive on

privacy and electronic

communications), OJ L 201, 31 July

2002, p. 37 ("E-Privacy

Directive")

Council Directive 2003/8/EC of 27 January

2003 to improve access to justice in cross-border disputes by establishing minimum common rules relating to legal aid for such disputes, OJ L 26, 31 January 2003, p. 41 ("Legal Aid

Directive") 1.12

Directive 2003/33/EC of the European

Parliament and of the Council of 26

May 2003 on the approximation of the laws, regulations and administrative provisions of the Member States relating to the advertising and sponsorship of tobacco products, OJ L 152, 20 June 2003 ("Tobacco

Advertising Directive") 5.03

Directive 2003/35/EC of the European Parliament and of the Council of 26

May 2003 providing for public participation in respect of the drawing up of certain plans and programmes relating to the environment and amending with regard to public participation and access to justice Council Directives 85/337/EEC and 96/61/EC, OJ L 156, 25 June 2003, p. 17 10.24

Directive 2004/17/EC of the European

Parliament and of the Council of 31

March 2004 coordinating the procurement procedures of entities operating in the water, energy, transport and postal services sectors, OJ L 134, 30 April 2004, p. 1

("Utilities Procurement

Directive") 3.02

Directive 2004/18/EC of the European

Parliament and of the Council of 31

March 2004 concerning the coordination of procedures for the award of public works contracts, public supplies contracts and public service 
contracts, OJ L 134, 30 April 2004, p. 114 ("Public Sector Procurement Directive") 3.02

Directive 2004/35/EC of the European

Parliament and of the Council of 21

April 2004 on environmental liability with regard to the prevention and remedying of environmental damage, OJ L 143, 30 April 2004, p. 56 ("Environmental Liability Directive") 1.10

Directive 2004/38/EC of the European Parliament and of the Council of 29 April 2004 on the right of citizens of the Union and their family members to move and reside freely within the territory of the Member States amending Regulation (EEC) No $1612 / 68$ and repealing Directives 64/221/EEC, 68/360/EEC, 72/194/EEC, 73/148/EEC, 75/34/EEC, 75/35/EEC, 90/364/EEC, 90/365/EEC and 93/96/EEC, OJ L 158, 30 April 2004, p. 77 1.09

Directive 2004/48/EC of the European Parliament and of the Council of 29 April 2004 on the enforcement of intellectual property rights, OJ L 195, 30 April 2004, p. 45 ("IPR

Enforcement Directive") 1.10

Directive 2005/29/EC of the European

Parliament and of the Council of 11

May 2005 concerning unfair

business-to-consumer commercial practices in the internal market and amending Council Directive 84/450/EEC, Directives 97/7/EC, 98/27/EC and 2002/65/EC of the European Parliament and of the Council and Regulation (EC) No 2006/2004 of the European Parliament and of the Council, OJ L 149, 11 June 2005, p. 22 ("Unfair Commercial

Practices Directive") 5.03

Directive 2005/60/EC of the European

Parliament and of the Council of 26

October 2005 on the prevention of the use of the financial system for the purpose of money laundering and terrorist financing, OJ L 309, 25 November 2005, p. 15 11.06

Directive 2006/54/EC of the European Parliament and of the Council of 5 July 2006 on the implementation of the principle of equal opportunities and equal treatment of men and women in matters of employment and occupation (recast), OJ L 204, 26 July 2006, p. 23 ("Gender Equality Directive") .... 1.09

Directive 2006/114/EC of the European Parliament and of the Council of 12 December 2006 concerning misleading and comparative advertising (codified version), OJ L 376, 27 December 2006 ("Misleading Advertising Directive") 5.03

Directive 2006/116/EC of the European Parliament and of the Council of 12 December 2006 on the term of protection of copyright and certain related rights (codified version), OJ L 372, 27 December 2006, p. 12 ..... 4.02

Directive 2006/123/EC of the European Parliament and of the Council of 12 December 2006 on services in the internal market, OJ L 376, 27

December 2006, p. 36 ("Services Directive") 1.03

Directive 2007/66/EC of the European Parliament and of the Council of 11 December 2007 amending Council Directives 89/665/EEC and 92/13/EEC with regard to improving the effectiveness of review procedures concerning the award of public contracts, OJ L 335, 20 December 2007, p. 31 ("Procurement Remedies Amending Directive") 3.09

Directive 2008/48/EC of the European Parliament and of the Council of 23 April 2008 on consumer credit agreements for consumers and repealing Council Directive 87/102/EEC, OJ L 1333, 22 May 
2008, p. 66 ("Consumer Credit

Directive") 5.03

Directive 2008/52/EC of the European

Parliament and of the Council of 21

May 2008 on certain aspects of mediation in civil and commercial matters, OJ L 136, 24 May 2008, p. 3

("Mediation Directive") 5.42

Directive 2008/95/EC of the European Parliament and of the Council of 22 October 2008 to approximate the laws of the Member States relating to trade marks (codified version), OJ L 299, 8 November 2008, p. 25 4.02

Directive 2009/22/EC of the European Parliament and of the Council of 23 April 2009 on injunctions for the protection of consumers' interests, $\mathrm{OJ} \mathrm{L}$ 110, 1 May 2009, p. 30 ("Consumer Injunctions Directive”) 1.10

Directive 2009/24/EC of the European Parliament and of the Council of 23 April 2009 on the legal protection of computer programmes (codified version), OJ L 111, 5 May 2009, p. 16

Directive 2009/48/EC of the European Parliament and of the Council of 18 June 2009 on the safety of toys, OJ L 170, 30 June 2009, p. 1 ("Toy Safety Directive") 5.03

Directive 2009/81/EC of the European Parliament and of the Council of 13 July 2009 on the coordination of procedures for the award of certain works contracts, supply contracts and service contracts by contracting authorities or entities in the fields of defence and security, and amending Directives 2004/17/EC and 2004/18/EC, OJ L 216, 20 August 2009, p. 76 ("Defence Procurement Directive") 3.02

Directive 2009/103/EC of the European Parliament and of the Council of 16 September 2009 relating to insurance against civil liability in respect of the use of motor vehicles, and the enforcement of the obligation to insure against such liability (codified version), OJ L 263, 7 October 2010, p. 11

("Motor Vehicle Insurance

Directive") 7.20

Directive 2011/7/EU of the European

Parliament and of the Council of 16

February 2011 on combating late payment in commercial transactions (recast), OJ L 48, 23 February 2011, p. 1

Directive 2011/35/EU of the European Parliament and of the Council of 5 April 2011 concerning mergers of public limited liability companies (codification), OJ L 110, 29 April 2011, p. 1 1.09

Directive 2011/83/EU of the European Parliament and of the Council of 25 October 2011 on consumer rights, amending Council Directive 93/13/EEC and Directive 1999/44/EC of the European Parliament and of the Council and repealing Council Directive 85/577/EEC and Directive 97/7 of the European Parliament and of the Council, OJ L 304, 22

November 2011, p. 64 ("Consumer Rights Directive") 5.03

Directive 2011/92/EU of the European Parliament and of the Council of 31 December 2011 on the assessment of the effects of certain public and private projects on the environment (codification), OJ L 26, 28 January 2012, p. 1 ("Environmental Impact Assessment Directive") ....... 1.09-1.10

Directive 2012/30/EU of the European Parliament and of the Council of 25 October 2012 on coordination of safeguards which, for the protection of the interests of members and others, are required by Member States of companies within the meaning of the second paragraph of Article 54 of the Treaty on the Functioning of the 
European Union, in respect of the formation of public limited liability companies and the maintenance and alteration of their capital, with a view to making such safeguards equivalent (recast), OJ L 315, 14 November 2012, p. 74 ("Public Limited Liabilities

Companies Directive") 1.09

Directive 2013/11/EU of the European Parliament and of the Council of 21 May 2013 on alternative dispute resolution for consumer disputes and amending Regulation (EC) No 2006/2004 and Directive 2009/22/EC (Directive on consumer ADR), OJ L 165, 18 June 2013, p. 63 ("Consumer ADR Directive") 5.42

Directive 2014/23/EU of the European Parliament and of the Council of 26 February 2014 on the award of concession contracts, OJ L 94, 28 March 2014, p. 1 ("Concessions Awards Directive”) 3.02

Directive 2014/24/EU of the European Parliament and of the Council of 24 February 2014 on public procurement and repealing Directive 2004/18/EC, OJ L 94, 28 March 2014, p. 65 ("New Public Sector Procurement Directive") 3.02

Directive 2014/25/EU of the European Parliament and of the Council of 26 February 2014 on procurement by entities operating in the water, energy, transport and postal services sectors and repealing Directive 2004/17/EC, OJ L 94, 28 March 2014, p. 243 ("New Utilities Procurement

Directive") 3.02

Directive 2014/52/EU of the European Parliament and of the Council of 16 April 2014 amending Directive 2011/92/EU on the assessment of the effects of certain public and private projects on the environment, OJ L 124, 25 April 2014, p. 1 $1.10,10.24$
Directive 2014/54/EU of the European Parliament and of the Council of 16 April 2014 on measures facilitating the exercise of rights conferred on workers in the context of freedom of movement for workers, OJ L 128, 30 April 2014, p. 8 ("Free Movement of Workers Enforcement Directive") 1.11

Directive 2014/67/EU of the European Parliament and of the Council of 15 May 2014 on the enforcement of Directive 96/71/EC concerning the posting of workers in the framework of the provision of services and amending Regulation (EU) No 1024/2012 on administrative cooperation through the Internal Market Information System ("the IMI Regulation"), OJ L 159, 28 May 2014, p. 11 ("Posting of Workers Enforcement Directive") 1.11

Directive 2014/104/EU of the European Parliament and of the Council of 26 November 2014 on certain rules governing actions for damages under national law for infringements of the competition law provisions of the Member States and of the European Union, OJ L 349, 5 December 2014, p 1 ("Competition Damages Directive") 1.11

\section{Regulations}

Council Regulation No 17 First Regulation implementing Articles 85 and 86 of the Treaty, OJ 13, 21 February 1962, p. 204

Council Regulation (EC) No 2100/94 of 27 July 1994 on Community plant variety rights, OJ L 227, 1 September 1994, p. 1 ("Community Plant Variety Rights Regulation”) ........4.02, 4.11, 8.33, 9.07

Council Regulation (EC) No 44/2001 of 22 December 2000 on jurisdiction and the recognition and enforcement of judgments in civil and commercial 
matters, OJ L 12, 16 January 2001, p. 1 1.12

Regulation (EC) No 1049/2001 of the

European Parliament and of the Council of 30 May 2001 regarding public access to European Parliament, Council and Commission documents, OJ L 145, 31 May 2001, p. 43 ("Transparency Regulation") 6.33

Council Regulation (EC) No 1206/2001 of 28 May 2011 on cooperation between the courts of the Member States in the taking of evidence in civil or commercial matters, OJ L 174, 27 June 2001, p. 1 ("Evidence

Regulation") $1.12,6.40$

Council Regulation (EC) No 6/2002 of 12

December 2001 on Community designs, OJ L 3, 5 January 2002, p. 1

("Community Designs

Regulation”) ...... 4.02, 4.11, 8.32-8.33, $9.15,10.14$

Council Regulation (EC) No 1/2003 of 16

December 2002 on the implementation of the rules on competition laid down in Articles 81 and 82 of the Treaty, OJ L 14 January 2003, p. 1

("Competition Regulation") 6.04

Council Regulation (EC) No 139/2004 of

20 January 2004 on the control of concentrations between undertakings,

OJ L 24, 29 January 2004, p. 1 .... 6.01

Regulation (EC) No 261/2004 of the

European Parliament and of the

Council of 11 February 2004

establishing common rules in

compensation and assistance to

passengers in the event of denied

boarding and of cancellation or long

delay of flights, and repealing

Regulation (EEC) No 295/91, OJ L

46, 17 February 2004, p. 1 ("Air

Passengers' Rights Regulation”) .. 1.11,

2.20, $7.20,9.18$

Regulation (EC) No 2006/2004 of the

European Parliament and of the

Council of 27 October 2004 on cooperation between national

authorities responsible for the

enforcement of consumer protection

laws, OJ L 364, 9 December 2004, p. 1

(“CPC Regulation”) 5.44

Regulation (EC) No 861/2007 of the

European Parliament and of the

Council of 11 July 2007 establishing a

European Small Claims Procedure,

OJ L 199, 31 July 2007, p. 1 ("Small

Claims Regulation”) .. 1.12, 5.36, 7.34,

8.31-8.32, 9.33, 10.49

Regulation (EC) No 864/2007 of the

European Parliament and of the

Council of 11 July 2007 on the law

applicable to non-contractual

obligations (Rome II), OJ L 199, 31

July 2007, p. 40 ("Rome II

Regulation”) ..... 1.12, 5.12, 7.23, 7.34,

Regulation (EC) No 1371/2007 of the

European Parliament and of the

Council of 23 October 2007 on rail

passengers' rights and obligations, $\mathrm{OJ} \mathrm{L}$

315, 3 December 2007, p. 14 ("Rail

Passengers' Rights Regulation”) .. 1.11,

$2.20,7.17,9.18,10.24$

Regulation (EC) No 765/2008 of the

European Parliament and of the

Council of 9 July 2008 setting out the

requirements for accreditation and

market surveillance relating to the

marketing of products and repealing

Regulation (EEC) No 339/93, OJ L

218, 13 August 2008, p. 30 5.44

Council Regulation (EC) No 207/2009 of

26 February 2009 on the Community

trade mark (codified version), OJ L 78,

24 March 2009, p. 1 ("Community

Trade Mark Regulation”) ... 4.02, 4.11,

4.21, 8.24, 8.32-8.33, 9.15

Regulation (EC) No 1060/2009 of the

European Parliament and of the

Council of 16 September 2009 on

credit rating agencies, OJ L 302, 17

November 2009, p. 1 .. 1.11, 7.06, 7.17 
Council Regulation (EC) No 1224/2009 of

20 November 2009 establishing a

Community control system for ensuring compliance with the rules of the common fisheries policy, amending Regulations (EC) No 847/96, (EC) No 2371/2002, (EC) No 811/2004, (EC) No 768/2005, (EC) No 2115/2005, (EC) No 2166/2005, (EC) No 388/2006, (EC) No 509/2007, (EC) No 676/2007, (EC) No 1098/2007, (EC) No 1300/2008, (EC) No $1342 / 2008$ and repealing Regulations (EEC) No 2847/93, (EC) No 1627/94 and (EC) No 1966/2006, OJ 343, 22

December 2009, p. 1 ("Fisheries

Control Regulation”) 2.20

Regulation (EU) No 1215/2012 of the

European Parliament and of the Council of 12 December 2012 on jurisdiction and the recognition and enforcement of judgments in civil and commercial matters (recast), OJ L 351, 20 December 2012, p. 1 ("Brussels I Regulation”) ..... 1.12, 4.21, 5.12, 7.34, 12.12

Regulation (EU) No 1257/2012 of the

European Parliament and of the Council of 17 December 2012 implementing enhanced cooperation in the area of the creation of unitary patent protection, OJ L 361, 31 December 2012, p. 1 4.02

Council Regulation (EU) No 1260/2012 of

17 December 2012 implementing enhanced cooperation in the area of the creation of unitary patent protection with regard to the applicable translation arrangements, OJ L 361, 31

December 2012, p. 89 4.02

Regulation (EU) No 524/2013 of the

European Parliament and of the Council of 21 May 2013 on online dispute resolution for consumer disputes and amending Regulation (EC) No 2006/2004 and Directive
2009/22/EC (Regulation on consumer ODR), OJ L 165, 18 June 2013, p. 1 ("Consumer ODR

Regulation”) $5.09,5.42,9.04$

Regulation (EU) No 608/2013 of the

European Parliament and of the Council of 12 June 2013 concerning customs enforcement of intellectual property rights and repealing Council Regulation (EC) No 1383/2003, OJ L 181, 29 June 2013 ("Customs

Enforcement Regulation”) 4.11 , 11.31

Regulation (EU) No 462/2013 of the

European Parliament and of the

Council of 21 May 2013 amending Regulation (EC) No 1060/2009 on credit rating agencies, OJ L 146, 31 May 2013, p. $146 \quad$....... 1.11, 7.06, 7.17

\section{Other Legislation}

Council Decision 80/271/EEC of 10

December 1979 concerning the conclusion of the Multilateral

Agreements resulting from the 1973 to 1979 trade negotiations, OJ L 071, 17

March 1980, p. 1 .3 .12

Council Decision 94/800/EC of 22

December 1994 concerning the conclusion on behalf of the European Community, as regards matters within its competence, of the agreements reached in the Uruguay Round multilateral negotiations (1986-1994), OJ L 336, 23 December 1994, p. 1 $3.12,4.12$

Commission Regulation (EC) No 1768/95 of 24 July 1995 implementing rules on the agricultural exemption provided for in Article 14(3) of Council Regulation (EC) No 2100/94 on Community plant variety rights, OJ L 173, 25 July 1995, p. 14 4.11 
Commission, Recommendation 98/257/EC on the principles applicable to the bodies responsible for out-of-court settlement of disputes, OJ L 115, 17 April 1998, p. 31 5.42

Commission, Recommendation 2001/310/EC of 4 April 2001 on the principles for out-of-court bodies involved in the consensual resolution of consumer disputes, OJ L 109, 19 April 2001, p. 56 5.42

Council Decision 2001/470/EC of 28 May 2001 establishing a European Judicial Network in civil and commercial matters, OJ L 168, 27 June 2001, p. 35 7.34

Council Framework Decision 2002/465/JHA of 13 June 2002 on joint investigation teams, OJ L 16220 June 2002, p. 1

Commission Regulation (EC) No 773/2004 of 7 April 2004 relating to the conduct of proceedings by the Commission pursuant to Articles 81 and 82 of the Treaty, OJ L 123, 27 April 2004, p. 18 ("Competition Proceedings

Regulation") 6.47

Commission Regulation (EC) No 874/2004 of 28 April 2004 laying down public policy rules concerning the implementation and functions of the .eu Top level Domain and the principles governing registration, $\mathrm{OJ} \mathrm{L}$ 162, 30 April 2004, p. 40 4.36

Council Framework Decision 2005/212/JHA of 24 February 2005 on confiscation of crime-related proceeds, instrumentalities and property, OJ L 86 15 March 2005, p. 49 .4 .38

Council Decision 2005/370/EC of 17 February 2005 on the conclusion, on behalf of the European Community, of the Convention on access to information, public participation in decision-making and access to justice in environmental matters, OJ L 124, 17 May 2005, p. 1 10.24

Commission Decision 2007/76/EC of 22

December 2006 implementing Regulation (EC) 2006/2004 of the European Parliament and of the Council on cooperation between national authorities responsible for the enforcement of consumer protection laws as regards mutual assistance, $\mathrm{OJ} \mathrm{L}$ 32, 6 February 2007, p. 192 ......... 5.44

Commission Decision 2010/233/EU of 26 April 2010 setting up the expert group on a common frame of reference in the area of European contract law, OJ L 105, 27 April 2010, p. 109 10.46

Commission, Recommendation 2010/304/EC of 12 May 2010 on the use of a harmonised methodology for classifying and reporting consumer complaints and enquiries, OJ L 136, 2 June 2010, p. 1 5.42

Commission, Recommendation 2013/396/EU of 11 June 2013 on common principles for injunctive and compensatory collective redress mechanisms in the Member States concerning violations of rights granted under Union law, OJ L 201, 27 June 2013, p. 60 ("Collective Redress Recommendation") 5.38

Commission Regulation (EU) No 1336/2013 of 13 December 2013 amending Directives 2004/17/EC, 2004/18/EC and 2009/81/EC of the European Parliament and of the Council in respect of the application thresholds for the procedures for the award of contracts, OJ L 335, 14 December 2013, p. 17 $3.02-3.03$ 
OFFICIAL DOCUMENTS - EU COMMISSION

\section{Commission Decisions, Statements, Guidelines and Notices}

Commission, Notice on agreements of minor importance which do not appreciably restrict competition under Article 81(1) of the Treaty establishing the European Community (de minimis), OJ C 368, 22 December 2001, p. 13 ("De minimis notice") 6.07

Commission, Guidelines on the application of Article 81(3) of the Treaty, OJ C 101, 27 April 2004, p. 97 .... 6.01-6.02

Commission, Notice on the handling of complaints by the Commission under Articles 81 and 82 of the Treaty, OJ C 101, 27 April 2004, p. 5 ("Complaints notice") 6.47

Commission, Notice on cooperation within the network of competition authorities, OJ C 101, 27 April 2004, p. 43

("Network notice") 6.50

Commission, Statement concerning Article 2 of Directive 2004/48/EC of the European Parliament and of the Council on the enforcement of intellectual property rights, OJ L 94, 13 April 2005, p. 37 ("Statement concerning Article 2 IPR Enforcement Directive 2004/48") $4.07,12.23$

Commission, Notice on the co-operation between the Commission and the courts of the EU Member States in the application of Articles 81 and 82 EC, OJ C 101, 27 April 2004, p. 54 ("Cooperation notice") ...... 6.04, 11.32

Commission, Guidelines on the method of setting fines imposed pursuant to Article 23(2)(a) of Regulation No 1/2003, OJ C 210, 1 September 2006, p. 2 ("Guidelines on fines")

Commission, Notice on immunity from fines and reductions of fines in cartel cases,
OJ C 298, 8 December 2006, p. 17

("Leniency notice") $6.48,6.51$

Commission, Decision C(2007) 512,

Elevators and escalators cartel, 21

February 2007 6.06

Commission, Notice on the conduct of settlement procedures in view of the adoption of decisions pursuant to Article 7 and Article 23 of Council Regulation (EC) No 1/2003 in cartel cases, OJ C 167, 2 July 2008, p. 1 ("Settlement notice") 6.04

\section{Commission Legislative Proposals}

Commission, Proposal for a Council directive relating to the approximation of the laws, regulations and administrative provisions of the Member States concerning liability for defective products, $\operatorname{COM}(76) 372$ final, 23 July 1976 ("Proposal for Product Liability Directive 85/374") $5.25-5.26,5.28,7.09$

Commission, Amendment of the proposal for a Council directive relating to the approximation of the laws, regulations and administrative provisions of the Member States concerning liability for defective products, $\mathrm{COM}(79) 415$ final, 26 September 1979 ("Amended proposal for Product Liability Directive 85/374") 5.25

Commission, Proposal for a Council directive on the coordination of the laws, regulations and administrative provisions relating to the application of Community rules on procedures for the award of public supply and public works contracts, $\operatorname{COM(87)~} 134$ final, 1 July 1987 ("Proposal for Public Sector Remedies Directive 89/665”) ...... 3.05, $3.08,3.16,3.33,7.19$

Commission, Amended proposal for a Council directive on the coordination of the laws, regulations and 
administrative provisions relating to the application of Community rules on procedures for the award of public supply and public works contracts, COM(88) 733 final, 8 December 1988 ("Amended proposal for Public Sector Remedies Directive 89/665”) ...... 3.05, 3.17, 3.33, 11.05, 12.33

Commission, Proposal for a Council directive on civil liability for damage caused by waste, $\operatorname{COM(89)} 282$ final, 15 September 1989 10.27

Commission, Proposal for a Council directive coordinating the laws, regulations and administrative provisions relating to the application of Community rules on the procurement procedures of entities operating in the water, energy, transport and telecommunications sectors, $\mathrm{COM}(90)$ 297 final, 30 July 1990 ("Proposal for Utilities Remedies Directive 92/13") .... 3.06, 3.10, 3.15-3.16, 3.25, 3.30, 7.04, 7.17, 7.19, 10.15, 11.06

Commission, Proposal for a Council directive on unfair terms in consumer contracts, COM(90) 322 final, 14 September 1990 ("Proposal for Unfair Terms Directive 93/13”) .....5.14, 5.16,

Commission, Proposal for a Council directive on the liability of suppliers of services, $\operatorname{COM}(90)$ 482, 20 December 1990 ("Proposal for a services liability directive") $5.34,10.27$

Commission, Proposal for a Council directive on the landfill of waste, $\operatorname{COM}(91) 102$ final, 22 May 1991 10.27

Commission, Amended proposal for a Council directive coordinating the laws, regulations and administrative provisions relating to the application of Community rules on the procurement procedures of entities operating in the water, energy, transport and telecommunications sectors, $\mathrm{COM}(91)$
158 final, 10 July 1991, p. 19

("Amended proposal for Utilities

Remedies Directive

92/13”) .............. 3.15-3.17, 3.30, 3.33

Commission, Amended proposal for a

Council Directive on unfair terms in consumer contracts, COM(92) 66 final, 4 March 1992 ("First amended proposal for Unfair Terms Directive 93/13") $5.13,5.16,8.03$

Commission, Re-examined proposal for a Council Directive on unfair terms in consumer contracts, $\mathrm{COM}(93) 11$ final, 26 January 1993 ("Second amended proposal for Unfair Terms Directive 93/13") 5.16

Commission, Proposal for a European Parliament and Council Directive on the sale of consumer goods and associated guarantees, $\mathrm{COM}(95) 520$ final, 19 June 1996 ("Proposal for Consumer Sales Directive 1999/44") 5.23

Commission, Proposal for a European Parliament and Council Directive on injunctions for the protection of consumers' interests, $\mathrm{COM}(95) 712$ final, 24 January 1996 ("Proposal for Consumer Injunctions Directive 2009/22") ......... 5.05-5.07, 5.11, 10.15

Commission, Amended proposal for a European Parliament and Council Directive on injunctions for the protection of consumers' interests, COM(96) 725 final, 23 December 1996 ("Amended proposal for Consumer Injunctions Directive 2009/22") 5.05

Commission, Proposal for a Council regulation on the Community patent, $\operatorname{COM}(2000) 412$ final, 1 August 2000 $4.02,7.24$

Commission, Proposal for a directive of the European Parliament and of the Council on measures and procedures to ensure the enforcement of intellectual property rights, $\operatorname{COM}(2003) 46$ final, 
30 January 2003 ("Proposal for IPR

Enforcement Directive

2004/48”) 4.03-4.04, 4.07, 4.09,

$4.12,4.14-4.16,4.20,4.22-4.23$,

4.25-4.27, 4.31-4.33, 4.38, 7.14, 7.16,

$7.22,7.25-7.26,9.02,9.18,10.04$

$10.15,12.41$

Commission, Proposal for a regulation of the

European Parliament and of the

Council on cooperation between

national authorities responsible for the

enforcement of consumer protection

laws, $\operatorname{COM(2003)~} 443$ final, 18 July

2003 ("Proposal for CPC Regulation

2006/2004")

5.43-5.44

Commission, Proposal for a regulation of the

European Parliament and the Council

on the law applicable to

non-contractual obligations ("Rome

II"), $\operatorname{COM(2003)~} 427$ final, 22 July

2003 ("Proposal for Rome II

Regulation 864/2007”)

Commission, Proposal for a directive of the

European Parliament and of the

Council on services in the internal market, $\mathrm{COM}(2004) 2$ final, 5 March 2004 ("Proposal for Services Directive 2006/123”) 5.34

Commission, Proposal for a Regulation of the European Parliament and of the Council establishing a European small claims procedure, $\operatorname{COM}(2005) 87$ final, 15 March 2005 ("Proposal for Small Claims Regulation 861/2007”) ... 8.31, 10.49

Commission, Amended proposal for a directive of the European Parliament and of the Council on criminal measures aimed at ensuring the enforcement of intellectual property rights, $\operatorname{COM}(2006)$ 168, 26 April 2006 ("Proposal for a directive on criminal measures for the enforcement of intellectual property rights") ....... 4.38,

Commission, Proposal for a directive of the European Parliament and of the
Council amending Council Directives 89/665/EEC and 92/13/EEC with regard to improving the effectiveness of review procedures concerning the award of public contracts, COM(2006) 195 final, 4 May 2006 ("Proposal for Procurement Remedies Amending Directive 2007/66") ... 3.09-3.10, 3.22, $3.34,7.04,8.04,8.07,11.06$

Commission, Proposal for a Directive of the

European Parliament and of the

Council on consumer rights,

COM(2008) 614 final, 8 October 2008

("Proposal for Consumer Rights

Directive 2011/83”) $5.22,5.35$ 10.46

Commission, Proposal for a Council

Decision on the conclusion of the

Anti-Counterfeiting Trade Agreement between the European Union and its Member States, Australia, Canada, Japan, the Republic of Korea, the United Mexican States, the Kingdom of Morocco, New Zealand, the Republic of Singapore, the Swiss Confederation and the United States of America, COM(2011) 380 final, 26 June 2011 ("Proposal for a decision on the conclusion of ACTA") 4.12

Commission, Proposal for a regulation of the European Parliament and of the Council on a common European sales law, $\operatorname{COM}(2011)$ 635, 11 October 2011 10.46

Commission, Proposal for a directive of the European Parliament and of the Council on alternative dispute resolution for consumer disputes and amending Regulation (EC) No 2006/2004 and Directive 2009/22/EC (Directive on consumer ADR), $\operatorname{COM}(2011) 793$ final, 29 November 2011 ("Proposal for Consumer ADR Directive 2013/11") 5.40-5.41

Commission, Proposal for a directive of the

European Parliament and of the

Council on procurement by entities 
operating in the water, energy, transport and postal services sectors, COM(2011) 895 final, 20 December 2011 ("Proposal for New Utilities

Procurement Directive 2014/25") 3.34

Commission, Proposal for a directive of the

European Parliament and of the

Council on public procurement, COM(2011) 896 final, 20 December 2011 ("Proposal for New Public Sector Procurement Directive 2014/24") $3.01,3.34$

Commission, Proposal for a regulation of the European Parliament and of the Council on the protection of individuals with regards to the processing of personal data and on the free movement of such data, COM(2012) 11 final, 25 January 2012 $1.11,8.24,12.39$

Commission, Proposal for a regulation of the European Parliament and of the Council amending Regulation (EC) No 261/2004 establishing common rules on compensation and assistance to passengers in the event of denied boarding and of cancellation or long delay of flights and Regulation (EC) No 2027/97 on air carrier liability in respect of the carriage of passengers and their baggage by air, $\mathrm{COM}(2013)$ 130 final, 13 March 2013 1.11

Commission, Proposal for a regulation of the European Parliament and of the Council on market surveillance of products and amending Council Directives 89/686/EEC and 93/15/EEC, and Directives 94/9/EC, 94/25/EC, 95/16/EC, 97/23/EC, 1999/5/EC, 2000/9/EC, 2000/14/EC, 2001/95/EC, 2004/108/EC, 2006/42/EC, 2006/95/EC, 2007/23/EC, 2008/57/EC, 2009/48/EC, 2009/105/EC, 2009/142/EC, 2011/65/EU, Regulation (EU) No 305/2011, Regulation (EC)
No 764/2008 and Regulation (EC) No $765 / 2008$ of the European Parliament and of the Council, $\operatorname{COM(2013)~75,~}$ 13 February 2013 ("Proposal for a regulation on market surveillance of products")

Commission, Proposal for a regulation of the

European Parliament and of the

Council on consumer product safety

and repealing Council Directive

87/357/EEC and Directive

2001/95/EC, COM(2013) 78 final, 13

February 2013 ("Proposal for a

regulation on consumer product

safety") $5.03,5.44-5.45$

Commission, Proposal for a directive of the European Parliament and of the Council to approximate the laws of the Member States relating to trade marks (recast), $\operatorname{COM(2013)~} 162$ final, 27 March 2013 4.02

Commission, Proposal for a directive on certain rules governing actions for damages under national law for infringements of the competition law provisions of the Member States and of the European Union, COM(2013) 404 final, 11 June 2013 ("Proposal for Competition Damages Directive 2014/104") ....... 6.07, 6.23, 6.25-6.32,
6.38, 6.40-6.42, 6.49, 7.14, 7.20, 8.19,
8.22, 9.03, 9.13, 9.20, 10.03, 10.30,
$10.37,11.05,11.09,11.26,11.34,12.33$

Commission, Proposal for a directive of the European Parliament and of the Council on package travel and assisted travel arrangements, amending Regulation (EC) No 2006/2004, Directive 2011/83/EU and repealing Council Directive 90/314/EEC, $\operatorname{COM}(2013) 512$ final, 9 July 2013 ("Proposal for a new package travel directive") $5.03,5.23,5.34$

Commission, Proposal for a directive of the European Parliament and of the Council on the protection of undisclosed know-how and business 
information (trade secrets) against their unlawful acquisition, use and disclosure, COM(2013) 813 final, 28 November 2013 ("Proposal for a trade secrets directive") $4.08,7.01$

7.26-7.27, 8.14, 8.21, 8.24, 8.26, 8.31, $9.01,9.10,10.38,11.26,12.23,12.40$

Commission, Proposal for a regulation of the

European Parliament and of the

Council amending Regulation (EC)

No 861/2007 of the European

Parliament and the Council of 11 July

2007 establishing a European Small

Claims Procedure and Regulation (EC)

No 1896/2006 of the European

Parliament and of the Council of 12

December 2006 creating a European

order for payment procedure, $\operatorname{COM}(2013) 794$ final, 19 November 2013

\section{Commission Green Papers, White}

\section{Papers and Reports}

Commission, Thirteenth report on competition policy, 1984 6.11

Commission, White paper on completing the internal market, $\mathrm{COM}(85) 310$ final, 14 June 1985 3.04

Commission, Green paper on access of consumers to justice and the settlement of consumer disputes in the single market, COM(93) 576 final, 16 November 1993 $5.01,5.04$

Commission, First report on the application of Council Directive on the approximation of laws, regulations and administrative provisions of the Member States concerning liability for defective products (85/374/EEC), COM(95) 617 final, 13 December 1995 ("First report on Product Liability Directive 85/374") $5.33,10.35$

Commission, Green paper on public procurement in the European Union: exploring the way forward, $\operatorname{COM}(96)$
583 final, 27 November 1996 ..... 3.17,

$3.34,7.03,7.22,10.34$

Commission, Green paper on combating counterfeiting and piracy in the single market, $\operatorname{COM(98)~} 569$ final, 15

October 1998 .. 4.03, 4.26, 4.38, 11.24

Commission, White paper on modernisation of the rules implementing Articles 85 and 86 of the EC Treaty, 28 April 1999, OJ C 132, 12 May 1999, p. 1 $6.04,6.13$

Commission, Green paper on liability for defective products, $\operatorname{COM}(1999) 396$ final, 28 July 1999 ...... 5.33, 7.01, 7.04

Commission, Report on the implementation of Council Directive 93/13/EEC of 5 April 1993 on unfair terms in consumer contracts, COM(2000) 248 final, 27 April 2000 ("Report on Unfair Terms Directive 93/13”) ... 5.33, 7.01,

Commission, Report on the application of Directive $85 / 374$ on liability for defective products, $\mathrm{COM}(2000) 893$ final, 31 January 2001, p. 10 ("Second report on Product Liability Directive 85/374") ......... 5.33, 7.03-7.04, 10.26

Commission, Green paper on European consumer protection, $\mathrm{COM}(2001) 531$

final, 2 October 2001 5.44

Commission, Green paper on damages actions for breach of the EC antitrust rules, $\operatorname{COM(2005)} 672$ final, 19

December 2005 ......... 6.17-6.18, 6.28, 7.03, 7.22, 7.25, 7.33, 8.31, 8.34, 10.35, $11.09,12.21$

Commission, Third report on the application of Council Directive on approximation of laws, regulations and administrative provisions of the Member States concerning liability for defective products (83/374/EEC) of 25 July 1985, amended by Directive 1999/34/EC of the European Parliament and of the Council of 10 May 1999, COM(2006) 496 final, 14 September 2006 ("Third report on 
Product Liability Directive

85/374") $5.25,5.33,7.04,10.26$

Commission, Green paper on the review of the consumer acquis, $\mathrm{COM}(2006) 744$

final, 8 February 2007 5.35

Commission, Communication on the implementation of Directive 1999/44 of the European Parliament and of the Council of 25 May 1999 on certain aspects of the sale of consumer goods and associated guarantees including analysis of the case for introducing direct producers' liability, $\operatorname{COM}(2007)$ 210 final, 24 April 2007 ("Report on Consumer Sales Directive 1999/44") 5.23

Commission, White paper on damages actions for breach of the EC antitrust rules, $\operatorname{COM}(2008) 165$ final, 2 April 2008 6.18, 6.29-6.30, 6.42, 6.45, 7.06, 7.19, 8.31, 9.18, 10.13, 10.30, $11.09,12.07,12.21,12.26$

Commission, Report on the application of Directive 98/27/EC of the European Parliament and of the Council on injunctions for the protection of consumers' interests, COM(2008) 756 final, 18 November 2008 ("First report on Consumer Injunctions Directive 2009/22") 5.09-5.12, 7.34

Commission, Green paper on consumer collective redress, $\operatorname{COM}(2008) 794$ final, 27 November 2008 ... 5.36-5.37, $8.32,11.26$

Commission, Report on the implementation of Directive 2001/95/EC of the European Parliament and of the Council of 3 December 2001 on general product safety, $\mathrm{COM}(2008)$ 905 final, 14 January 2009 ("Report on Product Safety Directive 2001/95") 5.44

Commission, Report on the application of Council Regulation (EC) No 44/2001 on jurisdiction and the recognition and enforcement of judgments in civil and commercial matters, COM(2009) 174 final, 21 April 2009 ("Report on Regulation 44/2001”) ....... 7.34, 12.08, 12.32

Commission, Communication on the report on the functioning of Regulation 1/2003, COM(2009) 206 final, 29 April 2009 ("Report on Competition Regulation 1/2003") .11 .32

Commission, Green paper on policy options towards a European contract law for consumers and businesses, $\mathrm{COM}(2010)$ 348 final, 1 July 2010 10.46

Commission, Report application of Directive 2004/48/EC of the European Parliament and of the Council of 29 April 2004 on the enforcement of intellectual property rights, COM(2010) 779 final, 22 December 2010 ("Report on IPR Enforcement Directive 2004/48”) ... 4.05, 4.07-4.09, 4.17-4.18, 4.23-4.24, 4.30, 4.34, $7.25,10.13$

Commission, Green paper on the modernisation of EU public procurement policy: towards a more efficient European procurement market, COM(2011) 15 final, 27 January 2011 .3 .02

Commission, White paper on a roadmap on a single European transport area: towards a competitive and resource efficient transport system, COM(2011) 144 final, 28 March 2011 10.46

Commission, Fourth report on the application of Council Directive 85/374/EEC of 25 July 1985 on the approximation of the laws, regulations and administrative provisions of the Member States concerning liability for defective products, amended by Directive 1999/34/EC of the European Parliament and of the Council of 10 May 1999, COM(2011) 547 final, 8 September 2011 ("Fourth report on Product Liability Directive 85/374") $5.33,7.04,10.26$ 
Commission, 28th Annual report on monitoring the application of EU law (2010), COM(2011) 588 final, 29

September 2011 2.17

Commission, Report on the application of Directive 2009/22/EC of the European Parliament and of the Council on injunctions for the protection of consumers' interests, $\mathrm{COM}(2012) 635$ final, 6 November 2012 ("Second report on Consumer Injunctions Directive 2009/22") ... 5.12, 7.34, 8.16, $8.25,8.28-8.29,10.20,11.06,11.32$, 12.33

Commission, 31st Annual report on monitoring the application of EU law (2013), $\operatorname{COM(2014)~} 612$ final, 1 October 2014 $2.17,11.16,11.27$

\section{Commission Communications}

Commission, Communication on unfair terms in contracts concluded with consumers, $\operatorname{COM(84)~} 55$ final, 14 February 1984

Commission, Supplementary communication on consumer redress, $\mathrm{COM}(87) 210$ final, 7 May 1987 5.04

Commission, Communication on the common position of the Council on the amended proposal for a directive on the coordination of the laws, regulations and administrative provisions relating to the application of rules on procedures for the award of public supply and public work contracts, SEC(89) 1196 final, 24 July 1989 ("Communication on the Council's position on the proposal for Public Sector Remedies Directive 89/665") $3.25,3.28,3.33$

Commission, Communication on the common position of the Council on the proposal for a directive on unfair terms in consumer contracts, $\mathrm{SEC}(92)$ 1944 final, 22 October 1992
("Communication on the Council's position on the proposal for Unfair Terms Directive 93/13") 5.16

Commission, Communication on new directions on the liability of suppliers of services, $\mathrm{COM}(94) 260$ final, 23 June 1994 5.34

Commission, Communication on an action plan on consumer access to justice and the settlement of consumer disputes in the internal market, $\mathrm{COM}(96) 13$ final, 14 February 1996 5.04

Commission, Report on the application of Articles 85 and 86 of the EC Treaty by national courts in the Member States, July 1997 6.12

Commission, Communication on public procurement in the European Union, COM(1998) 143 final, 11 March 1998 $1.03,3.17,3.34$

Commission, Communication on the common position of the Council on the proposal for a Directive of the European Parliament and of the Council amending Council Directive 85/374/EEC of 25 July 1987 on the approximation of the laws, regulations and administrative provisions of the Member States concerning liability for defective products, SEC(1998) 2232, 6 January 1999 ("Communication on the Council's position on the proposal for Product Liability Directive 85/374") 5.33

Commission, Communication on the follow-up to the green paper on combating counterfeiting and piracy in the single market, $\operatorname{COM}(2000) 289$ final, 30 November 2000 5.44

Commission, Communication on the follow-up to the green paper on EU consumer protection, $\mathrm{COM}(2002) 289$ final, 11 June 2002 5.44

Commission, Communication on the implications of the Court's judgment of 13 September 2005 (Case C-176/03, 
Commission v Council), COM(2005)

583 final, 23 November 2005 ..... 4.38,

11.27

Commission, Interpretative communication

on the Community law applicable to

contract awards not or not fully subject

to the provisions of the Public

Procurement Directives, OJ C 179, 1

August 2006, p. 2

Commission, Communication on the EU consumer policy strategy 2007-2013, $\operatorname{COM}(2007) 99$ final, 13 March 2007 5.35

Commission, Communication on guidance on the Commission's enforcement priorities in applying Article 82 of the EC Treaty to abusive exclusionary conduct by dominant undertakings, OJ C 45, 24 February 2009, p. 7 6.03-6.04

Commission, Communication on the enforcement of the consumer acquis, $\operatorname{COM}(2009) 330$ final, 2 July 2009 $5.35,5.44$

Commission, Communication on enhancing the enforcement of intellectual property rights in the internal market, $\operatorname{COM}(2009) 467$ final, 11 September 2009 4.03

Commission, Communication on a digital agenda for Europe, COM(2010) 245 final, 19 May 2010 5.42

Commission, Communication on a Single Market Act, COM(2011) 206 final, 13 April 2011 .5 .42

Commission, Communication on a single market for intellectual property rights: boosting creativity and innovation to provide economic growth, high quality jobs and first class products and services in Europe, COM(2011) 287 final, 24 May 2011 ..... 4.03, 4.08, 4.12

Commission, Communication towards an EU criminal policy: ensuring the effective implementation of EU policies through criminal law, $\operatorname{COM}(2011) 573$

final, 20 September 2011

Commission, Communication on the

Commission work programme 2012,

$\operatorname{COM}(2011)$ 777, 15 November

2011

Commission, Communication on alternative dispute resolution for consumer disputes in the single market, $\operatorname{COM(2011)} 791$ final, 29 November 2011 5.42

Commission, Communication on updating the handling of relations with the complainant in respect of the application of Union law, COM(2012) 154 final, 2 April 2012 2.17

Commission, Communication on more product safety and better market surveillance in the single market for products, COM(2013) 74 final, 13 February 2013 5.44

Commission, Communication towards a European horizontal framework for collective redress, COM(2013) 401 final, 11 June 2013 5.38, 11.12, 11.26

Commission, Communication on quantifying harm in actions for damages based on breaches of Articles 101 and 102 on the Treaty on the Functioning of the European Union, OJ C 167, 13 June 2013 .... 6.30-6.31, $7.15,10.30$

Commission, Communication towards a renewed consensus on the enforcement of intellectual property rights: an EU action plan, COM(2014) 392, 1 July 2014 $4.03,4.08,4.31,4.37$

\section{Other Commission Official Documents}

Commission, Information memo on the adoption by the Council of a preliminary programme for a consumer 
protection and information policy,

P-19/75, April 1975 5.04

Commission, Memorandum on consumer redress, $\mathrm{COM}(84) 629$ final, 12

December 1984 …...5.04, 10.26, 10.34

Commission, Press release intellectual property: Commission proposes directive to bolster the fight against piracy and counterfeiting, IP/03/144, 30 January 2003 ("Press release on the proposal for IPR Enforcement Directive 2004/48") 10.23

Commission, Responses to the consultation on the operation of national review procedures in the field of public procurement, $2004 \quad$..... 3.17, 3.34, 7.34

Commission, Staff working paper annex to the green paper on damages actions for breach of EC antitrust rules, SEC(2005) 1732, 19 December 2005 $6.13,6.17,6.28,6.30,7.04$

$7.13,7.25,7.33,8.34,10.35,12.37$

Commission, Staff working document impact assessment report on remedies in the field of public procurement, SEC(2006) 557 final, 4 May 2006 3.09, 3.13, 3.17-3.18, 3.27, 3.30, 3.33-3.34, 7.03-7.04, $10.34-10.35,11.06$

Commission, Report on the outcome of the public consultation on the review of the consumer acquis, 2007 5.35

Commission, Staff working paper accompanying the white paper on damages actions for breach of the EC antitrust rules, $\operatorname{SEC}(2008) 404$ final, 2 April 2008 $5.36,6.18,6.28-6.31$ $6.45,7.07-7.09,7.33-7.34,8.22$, 8.31-8.32, 9.07, 10.30, 10.35, 10.41, $10.46,11.09,11.12,11.23,11.38,12.21$

Commission, Staff working document impact assessment white paper on damages actions for breach of the EC antitrust rules, SEC(2008) 405 final, 2 April 2008 6.18

Commission, Questions and answers regarding the green paper on consumer collective redress, MEMO/08/741, 27

November 2008 $11.26,12.40$

Commission, Feedback statement on draft consumer collective redress benchmark consultation, 2008 ("Responses to the collective redress benchmark consultation") $5.37,7.25$

Commission, Overview of the results of the consultation on consumer collective redress, 2009 ("Responses to the consultation on consumer collective redress")

Commission, Summary of responses to the consultation launched to gather stakeholders' opinions on the existing problems and preferred solutions in order to identify preferred policy options as part of the Commission's review of the Package Travel Directive, March 2010 ("Responses to the consultation on Package Travel Directive 90/314") .....5.03, 5.23, 5.34, $7.06,7.20,8.01,12.15$

Commission, Working document on the results of the public consultation on the revision of the general product safety directive, 17 November 2010 ("Responses to the consultation on Product Safety Directive 2001/95") $5.03,5.44$

Commission, Staff working document analysis of the application of Directive 2004/48/EC of the European

Parliament and of the Council of 29 April 2004 on the enforcement of intellectual property rights in the Member States, SEC(2010) 1589 final, 22 December 2010 ("Staff working document accompanying the report on IPR Enforcement Directive 2004/48")

Commission, Staff working document on the public consultation towards a coherent approach to collective redress, SEC(2011) 173 final, 4 February 2011 ("Public consultation towards a 
coherent approach to collective redress") $1.07,5.36,11.12,11.26$

Commission, Working paper comments on the "Opinion of European academics on Anti-Counterfeiting Trade Agreement,"27 April 2011 ("Comments on the 'opinion of European academics on ACTA") 4.12

Commission, Note to file on the public hearing on Directive 2004/48/EC and the challenges posed by the digital environment, 7 June 2011 ("Responses to the public hearing on IPR Enforcement Directive 2004/48") 1.10

Commission, Staff working document evaluation report: impact and effectiveness of EU public procurement legislation, SEC(2011) 853 final, 27 June 2011 ("Report on the impact and effectiveness of EU public procurement legislation") ....... 3.10, 3.28-3.31, 3.34,

10.44

Commission, Synthesis of the comments on the Commission report on the application of Directive 2004/48/EC of the European Parliament and of the Council on the enforcement of intellectual property rights, July 2011 ("Responses to the report on IPR Enforcement Directive 2004/48”) 1.10

Commission (prepared by the University of Heidelberg), "Detailed minutes of the public hearing on towards a coherent European approach to collective redress, held in Brussels on 5 April 2011," 28 October 2011 ("Responses to the hearing on collective redress") .5 .37

Commission (prepared by the University of Heidelberg), "Evaluation of contributions to the public consultation and hearing 'Towards a coherent European approach to collective redress'," 28 October 2011 ("Responses to the consultation and hearing on collective redress") $5.37,8.32$

Commission, Consultation paper on the use of alternative dispute resolution as a means to resolve disputes related to commercial transactions and practices in the European Union, 2011

("Consultation paper on the use of alternative dispute resolution”) ..... 5.41

Commission, Civil enforcement of intellectual property rights: public consultation on the efficiency of proceedings and accessibility of measures, 2012 ("Consultation on the civil enforcement of intellectual property rights") 4.08

Commission, Synthesis of the responses civil enforcement of intellectual property rights: public consultation on the efficiency of proceedings and accessibility of measures, July 2013 ("Responses to the public consultation on the civil enforcement of intellectual property rights") $4.08,4.18,4.21$, 4.30, 4.36, 7.03, 7.30, 7.33-7.34, 8.29, 11.20

Commission, Staff working document on the annual public procurement implementation review 2012, SWD(2012) 342 final, 9 October 2012 $3.02,3.28-3.29$

Commission, Staff working paper impact assessment report on damages actions for breach of the EU antitrust rules, $\operatorname{SWD(2013)} 203$ final, 11 June 2013 .................. 6.07, 6.21, 6.23-6.25, 6.28-6.29, 6.37, 6.41-6.42, 6.45, 6.48-6.50, 7.06, 7.22, 8.21, 8.33-8.34, $9.26,10.21,10.32,10.34-10.35,10.41$, 10.46-10.47, 11.09, 11.26, 12.18, $12.33,12.40$

Commission, Staff working document practical guide on quantifying harm in actions for damages based on breaches of Article 101 and 102 of the Treaty on the Functioning of the European 
Union, SWD(2013) 205, 11 June

2013 $6.30,7.15,10.30$

\section{OFFICIAL DOCUMENTS - EUROPEAN PARLIAMENT}

European Parliament, Committee on legal affairs, document 246/78, 10 August 1978 10.04

European Parliament, Committee on legal affairs, document 71/79, 17 April 1979 10.04

European Parliament, Resolution of 13

March 1987 on consumer redress, OJ C 99, 13 April 1987, p. 203 5.01, 5.04, 9.02, 10.04 $10.26,12.41$

European Parliament, Resolution embodying the opinion of the European

Parliament on the proposal from the Commission of the European Communities to the Council for a Directive relating to the approximation of the laws, regulations and administrative provisions of the Member States concerning liability for defective products, OJ C 127, 21 May 1979 , p. 61 ("Opinion on the proposal for Product Liability Directive 85/374") .5 .25

European Parliament, Opinion on the proposal for a Council directive coordinating the laws, regulations and administrative provisions relating to the application of Community rules on the procurement procedures of entities operating in the water, energy, transport and telecommunications sectors, OJ C 106, 22 April 1991, p. 82 ("Opinion on the proposal for Utilities Remedies Directive 92/13”) 3.16

European Parliament, Committee on legal affairs and citizen's rights, Report on the proposal for a European Parliament and Council Directive on injunctions for the protection of consumers' interests, A4-0354/96, 5 November 1996 ("Report on the proposal for Consumer Injunctions Directive 2009/22") 5.05

European Parliament, Resolution on the Commission green paper on liability for defective products, A5-0061/2000, 30 March 2000 $5.33,7.04,10.26$

European Parliament, Committee on legal affairs and the internal market, Report on the proposal for a directive of the European Parliament and of the Council on measures and procedures to ensure the enforcement of intellectual property rights, A5_0468/2003, 5 December 2003 ("Report on the proposal for IPR Enforcement Directive 2004/48”) .....4.07, 4.31, 4.38

European Parliament, Legislative resolution on the proposal for a European Parliament and Council regulation on cooperation between national authorities responsible for the enforcement of consumer protection laws, P5_TA(2004)0296, 20 April 2004 ("Resolution on the proposal for CPC Regulation 2006/2004”) 5.44

European Parliament, Resolution of 25 April 2007 on the green paper on damages actions for breach of the EC antitrust rules, P6_TA(2007)0152 6.19

European Parliament, Policy Department, Study on safety and liability issues relating to package travel, document PE 393.520, January 2008 .. 5.34, 7.34

European Parliament, Resolution of 20 May 2008 on the EU consumer policy strategy 2007-2013, P6_TA(2008)0211 10.26

European Parliament, Resolution of 26 March 2009 on the white paper on damages actions for breach of the $\mathrm{EC}$ antitrust rules,

P6_TA(2009)0187 .... 6.19, 6.45, 8.32, $10.26,10.41-10.42,12.21,12.40$

European Parliament, Resolution of 10 March 2010 on the transparency and 
the state of play of ACTA negotiations,

P7_TA(2010)0058 4.12

European Parliament, Resolution of 24

November 2010 on the

Anti-Counterfeiting Trade Agreement

(ACTA), P7_TA(2010)0432 ........ 4.12

European Parliament, Resolution of 20

January 2011 on the report on

competition policy 2009,

P7_TA(2011)0023

European Parliament, Policy Department,

Study on cross-border alternative

dispute resolution in the European

Union, document PE 464.424, June

2011

European Parliament, Resolution of 2

February 2012 on towards a coherent

European approach to collective redress, P7_TA(2012)0021 ......... 1.07,

5.37, 7.24, 8.32, 10.42, 11.26,

$12.21,12.40$

European Parliament, Policy Department,

Study on collective redress in antitrust, document PE 475.120, June

2012

European Parliament, Legislative resolution of 4 July 2012 on the draft Council decision on the conclusion of the Anti-Counterfeiting Trade Agreement between the European Union and its Member States, Australia, Canada, Japan, the Republic of Korea, the United Mexican States, the Kingdom of Morocco, New Zealand, the Republic of Singapore, the Swiss Confederation and the United States of America, P7_TA-PROV(2012)0287 ("Legislative resolution on the draft Council decision on the conclusion of ACTA") 4.12

European Parliament, Committee on Economic and Monetary Affairs, Draft report on the proposal for a directive of the European Parliament and of the Council on certain rules governing actions for damages under national law for infringements of the competition law provisions of the Member States and of the European Union, 2013/0185(COD), 3 October 2013

("Draft report on the proposal for

Competition Damages Directive 2014/104") $6.30,6.34,6.43$

European Parliament, Committee on

Economic and Monetary Affairs,

Report on the proposal for a directive of the European Parliament and of the Council on certain rules governing actions for damages under national law for infringements of the competition law provisions of the Member States and of the European Union, A7-0089/2014, 4 February 2014

("Report on the proposal for Competition Damages Directive 2014/104") 6.29, 6.32, 6.34-6.35, $6.41,6.43,11.30$

\section{OFFICIAL DOCUMENTS - EU} COUNCIL

\section{Council Official Documents}

Council, Resolution of 14 April 1975 on a preliminary programme of the European Economic Community for a consumer protection and information policy, OJ C 92, 25 April 1975, p. 1 $5.02,5.04$

Council, Resolution of 29 June 1995 on the effective uniform application of Community law and on the penalties applicable for breaches of Community law in the internal market, OJ C 188 , 22 July 1995, p. 1 10.28

Council, Resolution of 19 December 2002 on amendment of the liability for defective products directive, OJ C 26, 4 February 2002, p. 2 ......... 10.13, 10.26

Council, Notice Agreement on a Unified Patent Court, OJ C 175, 20 June 2013, p. 1 4.02 
Council Preparatory Documents (available via an access to documents request to the Council)

Council, document 5555/80, 10 March 1980 $5.25,10.24$

Council, document 7772/80, 8 July 1980 10.24

Council, document 9976/80, 21 October 1980 10.24

Council, document 4161/81, 20 February 1981 10.24

Council, document 7020/81, 9 June 1981 5.25

Council, document 7945/81, 13 July 1981

Council, document 10512/81, 24 November 1981 5.26

Council, document 7413/84, 29 May 1984

Council, document 7669/85, 25 June 1985

Council, document 7834/89 ADD 1, 14 July 1989 $3.25,3.28,3.33,9.07,12.24$

Council, document 7490/89, 14 December 1989 $3.25,9.07$

Council, document 4176/91, 25 January 1991 10.04

Council, document 4904/91, 1 March 1991 10.04

Council, document 7250/91, 9 July 1991 $3.15-3.16$

Council, document 7333/91, 18 September 1991 3.15

Council, document 8406/1/92, 22 September 1992 5.16

Council, document 8406/1/92, 14 October 1992 5.16

Council, document 4884/93, 19 February 1993 5.16

Council, document 11674/96, 18 November 1996 $5.06,5.08$

Council, document 7562/98, 8 April 1998 10.04

Council, document 11107/03, 3 July 2003 4.07
Council, document 12055/03, 21 August 2003 4.27

Council, document 12450/03, 22 September 2003 4.07

Council, document 13027/03, 2 October 2003

Council, document 16289/03, 19 December 2003 4.31

Council, document 6052/04, 9 February 2004 $4.38,10.04$

Council, document 6299/04, 13 February 2004 10.04

Council, document 7073/04, 4 March 2004 5.44

Council, document 8285/04, 7 April 2004 4.38

Council, document 10329/06, 21 June 2006 4.38

Council, document DS 703/06, 5 October 2006

Council, document DS 802/06, 14

November 2006

Council, document DS 650/07, 31 January 2007

Council, document 8992/11, 18 April 2011

Council, document 16176/13, 18 November 2013 6.27, 10.04

Council, document 15979/13, 20 November 2013 6.27

Council, document 15983/13, 27 November 2013 $6.27,6.36,6.41,10.04$

Council, document 6493/14, 17 February 2014 6.34-6.36, 6.41, 6.43

Council, document 8088/14, 24 March 2014 $6.24,6.30-6.32$

Council, document 9870/14, 19 May 2014 9.10

\section{OTHER OFFICIAL DOCUMENTS}

Economic and Social Committee, Opinion on the proposal for a European Parliament and Council Directive on injunctions for the protection of 
consumers' interests, OJ C 30, 30

January 1997, p. 112 5.12

Council and Commission, Joint statement on the functioning of the network of competition authorities, 2002 6.50

European Parliament, Council and Commission, Interinstitutional agreement on better law-making, OJ C 321, 31 December 2003, p. 1 ...... 10.39

Economic and Social Committee, Opinion on the green paper damages actions for breach of EC antitrust rules, OJ C 324, 30 December 2006, p. 1 6.19

Explanations relating to the Charter of Fundamental Rights, OJ C 303, 14

December 2007, p. 2

Notice from the Member States, Rules governing prior consultation adopted by the Member States pursuant to Article 5 of Directive 98/27/EC of the European Parliament and of the Council on injunctions for the protection of consumers' interests, OJ C 181, 4 August 2009, p. 6 ("Rules governing prior consultation adopted pursuant to Article 5 of Consumer Injunctions Directive 2009/22”) .. 5.11

Eurobarometer, Consumer redress in the European Union: consumer experiences, perceptions and choices,
August 2009 http://ec.europa. eu/consumers/archive/redress_cons/ docs/cons_redress_EU_qual_ study_report_en.pdf ......... 7.34, 10.34,

Economic and Social Committee, Opinion on the white paper on damages actions for breach of the EC antitrust rules, OJ C 228, 22 September 2009, p. 40 6.19

European Data Protection Supervisor,

Opinion on the current negotiations by the European Union of an

Anti-Counterfeiting Trade Agreement (ACTA), OJ C 147, 5 June 2010, p. 1

Heads of the European competition authorities, Resolution on competition authorities in the European Union: the continued need for effective institutions, 16 November 2010 11.23

Heads of the European competition authorities, Resolution on the protection of leniency materials in the context of civil damages actions, 23

May 2012 6.23

Court of Justice, Rules of procedure, OJ L 265, 29 September 2012, p. 1 ..... 8.17, 
Folkert Wilman - 9781784718497 